\title{
The relationship between social change and religious movements
}

\author{
By KIRSTI SUOLINNA
}

\section{Analytical model}

The analytical model I have chosen here is based on the view of social change as a differentiated process, a process that changes the relationship between different groups in society. Change constitutes different things for the groups, as the position of one group may improve, but that of another deteriorate. Social change is a consequence of how the different groups act, and their actions again depend on their social and economic interests. In other words, there are groups in society (social classes, professional groups, the agrarian population, industrial workers), which come more or less openly in conflict with each other when looking after their interests. Thus this way of thinking is based on a conflict model. One sees social change as a consequence of people trying to protect their social and economic interests. Viewed this way even religious organizations and movements are involved in protecting the interests of social groups. However, the interesting point in this connection is that religious movements differ from political movements and groups, as the religious movements express the social interests of a group more indirectly than the political movements. The religious movements gather people from similar living conditions, and so to speak, prepare them for political work. They defend and justify the way of living of a group, and thus give ideological material for political groupings. They may also form coalitions with political groups and parties ${ }^{1}$.

This analytical model is very broad and may at first glance seem rather poorly fit for analyzing religious groups and for explaining dynamics and institutionalization among religious movements.

Nevertheless I am choosing this model as a frame and starting point, and

\footnotetext{
1 Cf. for example Appelbaum $81 \mathrm{ff}$.
} 
will in the following attempt to analyze Laestadianism from this point of view. Before going into the connection between religious dynamics and social change it is necessary to present a few general features of Laestadianism. In the following I will emphasize the features showing Laestadianism as a religious movement of the peasant population.

\section{Laestadianism as a peasant movement}

Laestadianism dates back more than hundred years, but for this description of its characteristic features we do not necessarily have to go back in time. Instead I will describe in short what Laestadianism is like today in northern Finland in Torneo river valley and specially in the Muonio district where I have conducted field work in the summer of $1976^{2}$.

In Muonio Laestadianism is viewed as a movement based on traditions. One does not believe that people from southern Finland would be able to understand Laestandianism. One does not expect people who move there to join the movement. However, one expects people from the Laestadian districts to understand the movement, e.g. people from the Uleaborg district. In general there is a strong expectation that people with laestadian family background are loyal to the movement. On the village level Laestadianism is a family tradition to such a degree that certain families are expected to give rise to preachers and leaders of the movement.

Also in the religious activities one leans on tradition. The older preachers defend old meeting patterns by referring to tradition. In their opinion one is not allowed to introduce into the program of the meeting new elements, such as e.g. new sacred music. The old simple meeting patterns have to be preserved. "The old bad food has to be good enough for the believer" these preachers say.

It is easy to see in the Muonio district how the laestadian religious pattern fits the old agrarian society. Thus, one demands great humility of all preachers. No one should strive too eagerly to become a leader of others, rather, one should be elected leader and preacher almost against one's will. A combination of personal humility and collective unity is still characteristic of Laestadianism in the Muonio district.

In its original surrounding, the village community, Laestadianism is a collective form of religion. People also like to refer to the destiny of the

${ }^{2}$ In Muonio I had three coworkers Kaisa Sinikara, Ilmo Massa and Yrjö Viitikko. 
people of Israel, and see the Laestadians as a chosen people in the same way.

The characteristic feature of the meetings are the long sermons, that work through an emotional communication between the preacher and the participants of the meetings. In the sermons one strives for an emotional receiving of the word and therefore uses very little intellectual arguments. The meetings sometimes give rise to a very strong feeling of togetherness, especially when both preacher and participants get into, or experience, socalled emotions (likutuksia). From the emotionally coloured sermons one could come to the conclusion that Laestadianism is a moralistic movement, but as a matter of fact the tendency is the opposite. The emphasis of sin as omnipresent, and the strong emotional charge can cause collective discharge of great dimensions. In those cases sin almost gets an aura of virtue. In the moment of the emotional outburst one can forget all the problems of everyday life and conventions. One can reach a kind of social or religious intoxication which at once solves all the problems ${ }^{3}$. Strong emotional ties are so formed among the followers. However, the followers are not led to an individualistic christianity such as the one e.g. the fifth revivalist movement is trying to accomplish.

Laestadianism is thus not an individualistic form of religion. It is not a moralistic movement. The movement does emphasize certain norms, but these concern mostly the roles of women and men, and the relationship to outsiders, to the surrounding world. Thus the division of labour between man and woman has to be clearly staked. The woman is a housewife and childbearer. Birth control is not to be used, as it is according to the law of nature (and the law of God) that man shall multiply. Man is the woman's head, and the decision making in general questions is a privilege of the man. Seen against this background one can even understand the negative attitude in the question of women ministers.

Alcohol is absolutely prohibited. In general the believers are expected to have a cautious attitude to the secular surrounding. The Laestadians speak in negative terms of TV, magazines and other entertainment, but one does not analyze these phenomena. The struggle against them is conducted in a way, which intellectually seems very stereotyped. Amusements simply remove the believer from the love of Christ and the community of believers.

${ }^{3}$ Cf. also Gothoni 192 ff. 


\section{The attitude of laestadian movements to tradition}

I think that this kind of relatively detailed description, as I have just given, is necessary before one can do an actual analysis of how Laestadianism relates to changes in society.

The agrarian revivalist movements are known for their conservatism, for their tendency to hold on to old established patterns. Even in secular matters the agrarian communities are known for their resistance to innovations coming from cities and centers. It is however also known that some novelties are embraced, whereas others meet resistance ${ }^{4}$. The conservatism is thus not without gaps. It is rather interesting to take a closer look at the way revivalist movements choose their traditional elements. In the conflicts within Laestadianism the issue becomes how to justify and defend one's position. The debating Laestadians look for justification in tradition. The ones who consider themselves representatives of the original form, also think that they have thus proven their genuineness (cf. the names "Firstborn", "Old Laestadians").

Paradoxically enough, looking for support in tradition sometimes requires innovations, although very conserving innovations. Thus, e.g. certain clothing has been preserved by the Western Laestadians. The believing man is not supposed to wear a tie, and the believing woman is required to wear a head scarf. In other words, the way the believers dress has been made uniform. The origin of this innovation is in completely ordinary ways of dressing among the peasant population. But clothes have been given religious symbolic value. The habit of wearing such clothes identifies a person as a believer. The traditional clothes have thus been given symbolic value for religion, and made part of the religious tradition.

In the same way the meeting patterns have symbolic value. It has become especially important for Laestadianism to preserve the laestadian "emotions" (liikutukset) as a sign of true christianity.

The traditional elements are most naturally chosen in connection with conflicts within Laestadianism. These elements will divide the groups. However, the changes in the community are also involved in this process. The religious differences do not come from nowhere, but rather, the religious differentiation gets its driving force from community changes. The most traditionbound laestadian movement, i.e. the Western Laestadianism

\footnotetext{
${ }^{4}$ For an overview see Wolf $77 \mathrm{ff}$.
} 
is found in the northern most part of Sweden (center in Gällivare). In this very branch one reads the sermons of Laestadius in the old way, the patterns of the meetings are extremely oldfashioned, and in addition the above mentioned way of dressing is characteristic for them. By holding on to this kind of traditional elements the Western Laestadians, as I mentioned, draw the line between themselves and other laestadian groups. At the same time they however also draw a sharp line between their community and outsiders. The Western Laestadians are a very closed group. The traditional elements make it easy for those belonging to the group to participate in activities, but make it difficult for outsiders to get in at all. One can rise the question why it has been so important for the Western Laestadians to draw such a line between themselves and the surrounding. How does it affect the dynamics? Other surroundings are known where such religious groups have formed closed, small farming communities. Such communities have been formed e.g. by the Hutterites in USA and Canada. The Hutterites live in closed, independent colonies. The line to the environment is sharp. The followers do not participate in any political activities, they renounce secular careers and stay with the main livelyhood, agriculture. As the Hutterites do not participate in political activities they cannot influence the prices of their agricultural products, but sell them at going prices. But since they own big farming units they are rather unaffected by fluctuations in prices. In this connection I want to emphasize that the Hutterites do not draw the line between believers and non-believers in their own group, but instead the line goes between their local community and the outside world ${ }^{5}$.

Among the laestadian movements the Western Laestadians have come closest to the solution of the Hutterites. In other words, the border between the outside world and the believers is one between the local community (or a pocket in it) and the national society. In northern Sweden the social changes have favoured the creation of exceptionally closed groups. In Norrbotten industrialization has been founded on mining and partly on forest industry. The manpower for mining has come from other parts of the country. At the same time, especially during the last decades, farming has become greatly rationalized, and large farming units have been formed. Thus there is an agrarian, Finnish original population, and an urban and industrial population, which has come from the outside. In addition moving

5 Cf. Bennett $441 \mathrm{ff}$; also Eaton $92 \mathrm{ff}$.

4-772570 H. Biezais 
away from the farming region has been great. All this has favoured the development towards isolation ${ }^{6}$.

As a background to this process I want to mention the connection between Laestadianism and economy, which $\mathrm{O}$. Brox has pointed out. In an interesting article Brox maintains, that there is a connection between the hostility of the peripheral villages towards the world, and their economic interests. A rather typical peripheral village in northern Norway has built its economy on a combination of natural economy and trade with fish. The economy of the village is so autonomous, that any interference by the national society is seen as negative. The inhabitants are thus not interested in road connections with the center, neither in electricity. The inhabitants of the village know that a welfare society does not offer its services without counter services. "Accepting the gifts of the welfare society means accepting eviction at the same time" the villagers feel ${ }^{7}$. Brox further points out that it is no wonder that these villagers are Laestadians, and through Laestadianism give voice to their suspicion of the national society ${ }^{8}$. One could say that through their traditional orientation the Western Laestadians are trying to create a local community, which as far as possible is independent of the national society. However, such a solution requires a good economic foundation. The Western Laestadians have this foundation in their farming and their businesses. I want to emphasize in this connection that the example given by Brox is valid for peripheral village communities whose economic autonomy is based on a combination of natural and monetary economy. The present economy of the Western Laestadians is dependent on the monetary economy in a different way. Historically Laestadianism evidently has participated in defending the peripheral communities against the advancing capitalism, i.e. monetary economy and its binding forces. The rationalized farming is dependent on monetary economy in a very different way than the peripheral villages were (and still are to a certain degree). In spite of this there is among these newer farming communities a desire to distance themselves from the national society. But in order to become a really strong tendency even other factors are required

\footnotetext{
${ }^{6}$ For more detailed information about differences in the Laestadian movement on the Finnish and the Swedish side of Torneo river valley cf. Suolinna, Kirsti, 1971, $89 \mathrm{ff}$.

${ }^{7}$ Brox 176.

${ }^{8}$ Cf. Brox 177.
} 
than farming in an industrialized surrounding alone. An important additional factor are the ethnic and linguistic differences between people. For an ethnic/linguistic minority with a differing economy it may be tempting to withdraw from the political circles of the national society. In Finland Laestadianism is closer to the community than in northern Sweden or maybe even in Norway ${ }^{9}$. Here the Laestadians do not draw such a sharp line between believers and non-believers. Prominent laestadian preachers hold political positions of trust and are active in boards and associations. These leaders even try to influence Laestadianism towards a less traditional and more open modern direction.

\section{The choice between collectivism and individualism}

The social development has thus in Sweden caused an isolation and traditional institutionalization of Laestadianism. The change means that the followers have become fewer, and the movement refrains from getting involved in secular and political questions. The possibilities of the movement to influence the surrounding have diminished at the same time. The movement is in danger of losing all dynamic character and becoming a reservation for an ever smaller group of individuals. It is worth noting that this change is not due to internal properties of Laestadianism, but is due to the interaction between a certain type of social surrounding and the laestadian movement.

In another surrounding Laestadianism has developed in another direction. Western Laestadianism has developed towards collectivity and isolation. Among the Eastern Laestadians some factions have developed towards individualism and assimilation with official church life. I am referring here mainly to the Newly Awakened (uusheränneet) and to a certain degree also to the "Small Firstborns" (pikkuesikoiset) in Torneo river valley and in the Muonio district. One could say that the tension between collectivism and individualism within Laestadianism is old, and belongs to the frequent splittings within the movement. In order to describe this tension, and in order to see what kind of possibilities the individualistic solution offers, again I have to make reference to Laestadianism in the Muonio district.

In the Muonio district the situation of the farming population has

\footnotetext{
9 The situation on the local plan in Norway is analysed by Paine, see especially $180 \mathrm{ff}$.
} 
changed dramatically during the last two decades. The change has not given rise to bigger farming units, but rather has forced people to completely give up farming. E.g. in Ylimuonio, which earlier was such a prosperous farming village, the fields are not cultivated, and the cattle raising has been given up (in this big village there are today only three farms with cattle). The population has switched to other professions, moved to northern Sweden. The educated ones have moved to the bigger communities on the Finnish side. The older population has remained in the village and gets different kinds of pensions. The change has not everywhere been as dramatic as in Ylimuonio, but in many communities in northern Finland the share of farming and forestry as a livelyhood has diminished rapidly, and in many places farms have been abandoned. The development is not only one of rationalization of farming, which also in itself releases people from this livelyhood. It is of course conceivable, that people in this situation of great change would hold on to tradition even more, and isolate themselves. This tendency does exist. It can be seen in the older preachers when they speak about "the old bad food". But we have to realize that the solution lacks economic foundation. A sufficiently big group of economically autonomous farmers is lacking. The other solution then is to try to renew the movement, and specially try to serve the needs of young people. Right now progressively oriented Laestadians have introduced activities specially intended for young people. This is sensational as Laestadianism traditionally is opposed to all direct activities for young people. The progressive leaders are also trying to renew the style of the sermons. They use intellectual arguments, and they teach and encourage in their sermons. One can also notice a subtle effort to soften the attitude towards female and male roles.

The present leaders cannot give identity to the movement as the identity source is in tradition. Through their softened, more individualistic view of christianity they take Laestadianism in a universal christian and churchoriented direction. From the traditional laestadian point of view their activity is disruptive.

We have come to the conclusion, that for such an agrarian religion as Laestadianism there are no other solutions than collectivism and isolation on one hand, or individualism and fusion on the other. The course of development chosen by the movement has been dependent on the social surrounding and the changes in it. 


\section{Laestadianism as an interest movement}

One can divide the social interest protected by Laestadianism as follows:

1) Laestadianism as a peripheral movement, i.e. its interest in preserving natural economy and the economic autonomy of the peripheral regions.

2) Laestadianism as a spokesman for the agrarian population, i.e. its interest in preserving the village community and farming as the basic livelyhood.

3) Laestadianism as a spokesman for linguistic and ethnic minorities (Lapps, Finns).

4) Laestadianism as a spokesman for big farmers and business men.

All these aspects have influenced and still influence the development of Laestadianism. However, in different surroundings the emphasis has been different. From a historic point Laestadianism has been a peripheral movement and has been a spokesman for the agrarian population. The minority problems have become acute later, and also the interest to protect specifically the way of life of big farmers.

Brox maintains that the turning away from the world by Laestadianism fits the economic interests of the peripheral village ${ }^{10}$. In spite of being logical, such an interpretation has certain weaknesses. The general distrust of the bad world is a life philosophy on a very general level, whereas economic interests have a very concrete character. In other words, the explanation of Brox lacks information about the way this view of the world has been formed in a more concrete way, and how it has affected the actions of people. I have in the foregoing tried to describe such mechanism. All laestadian movements speak about the bad world, the $\sin$ in the world and in man, but nevertheless the line between the believers and non-believers is drawn with different sharpness. A religious movement has dynamic power only as long as there is some kind of communication between supporters and non-supporters. Most of the laestadian movements still have such dynamic power, even though the adherence to tradition is strong, and the line to the surrounding is clear.

In the church-sect theory the basic thought has been that a religious movement with time develops into a church. A sect becomes a church and from this church sects will again split, who want to return to the original

${ }^{10} \mathrm{Cf}$. Brox $167 \mathrm{ff}$. 
and true christinaity ${ }^{11}$. This theory is based on some real observations, but it conceals some other important phenomena. The sect-church view conceals the social factors behind the development in an eccelsiastical direction. It conceals the fact that a "sect" can have a strongly institutionalizing element, one does not deal only with spontaneity in activities. The Western Laestadians are a case in point. One can see the Western Laestadianism as a sectarian movement, as a group that has split from the Laestadianism, but that could easily lead to forgetting the strong process of institutionalization; the development has gone from a more open community towards a more and more closed one.

Already in the 1860 s there was in the then united Laestadianism a more moderate form of institutionalization, than what later has taken place within the Western Laestadianism. P. Raittila, a church historian, has shown that the eschatological way of thinking which was prominent within Laestadianism during the first two decades, gave way to an increasingly stronger emphasis on the unity of the believers ${ }^{12}$. This meant exactly an effort to draw a clear line between Laestadians and outsiders. Since this institutionalization, which was necessary for the continuity, Laestadianism has struggled with the tension between the collectivistic and individualistic tendencies.

Collectivism implies in a manifest sense an alienated solution, but since the separation has been to strong, it has in a latent way been an adaptation to the surrounding. This adaptation involves that the movement does not have to concern itself with the bad world, but it has to passively adapt itself to what is happening in the surrounding. The collective form of community created by the Western Laestadianism is a counter culture in the capitalistic surrounding. The passiveness and distance taking involves at the same time an acceptance by the movement of existing social conditions; the alienated solution goes along with political conservatism.

We have here a classic dilemma. Puritanism was faced by the same problem. R. Tawney emphasizes in his analysis of Puritanism that there existed a tension between collectivistic and individualistic elements. The fact that the individualistic elements got the upper hand made it possible for Puritanism to contribute to the rise of capitalism in England ${ }^{13}$. We may

${ }^{11}$ See for example Yinger $142 \mathrm{ff}$.

12 Cf. Raittila $247 \mathrm{ff}$.

${ }^{13}$ Cf. Tawney $197 \mathrm{ff}$. 
now ask how this adaptation within Puritanism took place. Tawney's analysis is not altogether clear on this point. In his opinion Puritanism had unintended effects, the goal of Puritanism was collective discipline, but practically its result was freedom ${ }^{14}$. Theoretically we can think that this took place in the same way as within Laestadianism much later and on a smaller scale. The movement could dissociate itself from the social surrounding to a degree where this in practice meant adaptation to capitalism. In other words, a similarity between the Puritanism of the seventeenth and eighteenth century and the Western Laestadianism of the twentieth century is suggested. The fact that the individualistic elements became dominating, could also be taken as a secularization and assimilation with church of Puritanism, and thus supporting capitalism. In this connection we cannot settle the question as far as Puritanism is concerned ${ }^{15}$. In any case, the effects of the individualistic solution are more difficult to master and survey theoretically. However, I consider it to be a more interesting and intricate process. In my opinion therefore, the less collective or more open laestadian movements are more interesting than the Western Laestadians, and worth studying empirically.

\section{Bibliography}

Appelbaum, R., 1970, Theories of Social Change. Chicago.

Bennett, J., 1967, Microcosm-Macrocosm Relationships in North American Agrarian Society. American Anthropologist 69.

Brox, O., 1964, Avvisning av storsamfunnet som ökonomisk tilpasningsform. Tidskrift for samfunnsforskning 5.

Eaton, J., Weil, R., 1967, The Mental Health of the Hutterites. Mental Illness and Social Processes. New York.

Gothoni, R., Suolinna, Kirsti, 1975, The Religious Message in Action-A Case Study. Scripta Instituti Donneriani Aboensis 7, Uppsala.

Paine, R., 1965, Coast Lapp Society II, A Study of Economic Development and Social Values. Tromsö Museums skrifter 4, 2. Tromsö.

Raittila, P., 1976, Lestadiolaisuus 1860-luvulla, Leviäminen ja yhteisönmuodostus. Loimaa.

Suolinna, Kirsti, 1971, Den laestadianska väckelserörelsen i Tornedalen. Studier kring gränsen $i$ Tornedalen. Stockholm.

- 1975, Uskonnollisten liikkeitten asema sosiaalisessa muntoksessa. Research Reports. University of Helsinki, Institute of Sociology 203. Helsinki.

Tawney, R., 1969, Religion and the Rise of Capitalism. London.

Wolf, E., 1966, Peasants. Englewood Cliffs, N.J.

Yinger, J., 1957, Religion, Society and the Individual. New York.

${ }^{14}$ Cf. ib. $232 f$.

15 A more detailed interpretation is offered in Suolinna, Kirsti, 1975, $5 \mathrm{f}$. 